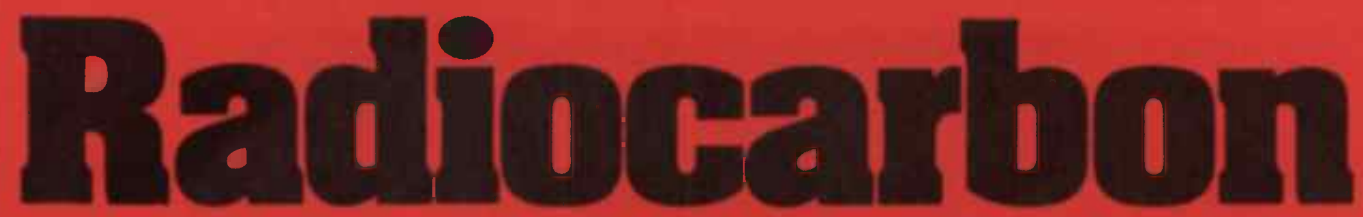

Published by THE AMERICAN JOURNAL OF SCIENCEE

\title{
Editor
}

MINZE STUIVER

\section{Associate Editors}

To. serve until January 1, 1989

STEPHEN C PORTER Seattle, Washington

To serve until January 1, 1986

W G.MOOK Groningen, The Netherlands

HANS. OESCHGER Bern, Switzerland

To serve until January 1, 1987

RONALDB DAVIS Orono, Maine

To serve until January 1, 1990

ANDREW MOORE

\section{Managing Editor}

RENEE S KRA

Kline Geology Laboratory

Yale University

New Haven, Connecticut 06511 


\section{TWELFTH INTERNATIONAL RADIOCARBON CONFERENCE \\ June 24-28, 1.985 \\ Trondheim, Norway}

The Twelfth International Radioçarbon Cónference will be held from June 24 to 28,1985 at the Norwegian Institute of Technology, Trondheim, Norway.

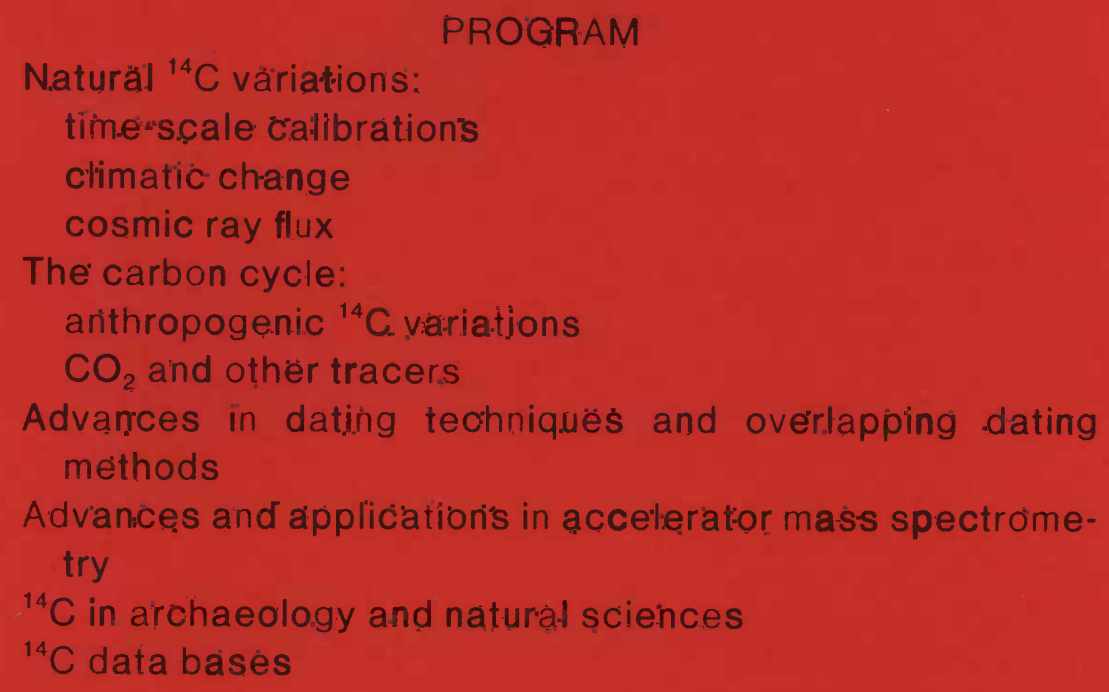

\section{PAPERS}

Acceptancè of papers will be based on extended summarie-s of approximately 200 words. Papeirs may be submitted for oral presentatión or poster sesșion.s. Papeirs will be selected for publication in a special proceedings issue of RADIOCARBON.

For further information, write:

The 12 th International Radiocarbon Conference

Attn: Pat Uelarid

Studies and Academic Administration

The Norwegian In.stitute of Technology

N-7034 Trondheim-NTH, Nörwày 


\section{NOTICE TO READERS AND CONTRIBUTORS}

Since its inception, the basic purpose of Radiocarbon has been the publication of compilations of ${ }^{14} \mathrm{C}$ dates produced by various laboratories. These lists are extremely useful for the dissemination of basic ${ }^{14} \mathrm{C}$ information.

In recent years, Radiocarbon has also been publishing technical and interpretative articles on all aspects of ${ }^{14} \mathrm{C}$. We would like to encourage this type of publication on a regular basis. In addition, we will be publishing compilations of published and unpublished dates along with interpretative text for these dates on a regional basis. Authors who would like to compose such an article for his/her area of interest should contact the Managing Editor for information.

Our new associate editor for Archaeology, Andrew Moore, is a prehistoric archacologist who recently became an assistant professor in the Department of Anthropology at Yale University. He received his doctorate from Oxford University and has also taught at the University of Arizona. His research is mainly concerned with the origins of agriculture and sedentary life in Southwest Asia. He is interested, further, in the prehistory of Europe, prehistoric economies, and theory and method in archaeology.

Another section is added to our regular issues, "Notes and Comments." Authors are invited to extend discussions or raise pertinent questions to the results of scientific investigations that have appeared on our pages. The section includes short, technical notes to relay information concerning innovative sample preparation procedures. Laboratories may also seck assistance in technical aspects of radiocarbon dating. Book reviews will also be included for special editions.

Manuscripts of radiocarbon papers should follow the recommendations in Suggestions to Authors* and RADIOCARBON Stylc Guide (R, 1984, v 26, p 152-158). Our deadline schedule is:

\section{For Date}

$\begin{array}{ll}\text { Vol 27, No. 3, } 1985 & \text { May 1, } 1985 \\ \text { Vol 28, No. 1, } 1986 & \text { Sept 1, } 1985\end{array}$

Vol 28, No. 2, $1986 \quad$ Jan 1, 1986

Half life of ${ }^{14} \mathrm{C}$. In accordance with the decision of the Fifth Radiocarbon Dating Conference, Cambridge, 1962, all dates published in this volume (as in previous volumes) are based on the Libby value, $5570 \pm 30 \mathrm{yr}$, for the half life. This decision was reaffirmed at the 11 th International Radiocarbon Conference in Seattle, Washington, 1982. Because of various uncertainties, when ${ }^{14} \mathrm{C}$ measurements are expressed as dates in years BP the accuracy of the dates is limited, and refinements that take some but not all uncertainties into account may be misleading. The mean of three recent determinations of the half life, $5730 \pm 40 \mathrm{yr}$, (Nature, $\mathrm{v} 195$, no. 4845, p 984, 1962), is regarded as the best value presently available. Published dates in years BP can be converted to this basis by multiplying them by 1.03 .

$A I / B C$ Dates. In accordance with the decision of the Ninth International Radiocarbon Conference, Los Angeles and San Diego, 1976, the designation of AD/BC, obtained by subtracting AD 1950) from conventional BP determinations is discontinued in Radiocarbon. Authors or submitters may include calendar estimates as a comment, and report these estimates as $\mathrm{AD} / \mathrm{BC}$, citing the specific calibration curve used to obtain the estimate.

Meaning of $\delta^{14} C$. In Volume 3, 1961, we endorsed the notation $\Delta$ (Lamont VIII, 1961) for geochemical measurements of ${ }^{14} \mathrm{C}$ activity, corrected for isotopic fractionation in samples and in the NBS oxalic-acid standard. The value of $\delta^{14} \mathrm{C}$ that entered the calculation of $\Delta$ was defined by reference to Lamont VI, 1959, and was corrected for age. This fact has been lost sight of, by editors as well as by authors, and recent papers have used $\delta^{14} \mathrm{C}$ as the observed deviation from the standard. At the New Zealand Radiocarbon Dating Conference it was recommended to use $\delta^{14} \mathrm{C}$ only for age-corrected samples. Without an age correction, the value should then be reported as percent of modern relative to 0.95 NBS oxalic acid (Proceedings 8th Conference on Radiocarbon Dating, Wellington, New Zealand, 1972). The Ninth International Radiocarbon Conference, Los Angeles and San Diego, 1976, recommended that the reference standard, 0.95 times NBS oxalic acid activity, be normalized to $\delta^{13} \mathrm{C}=-19 \%$

In several fields, however, age corrections are not possible. $\delta^{14} \mathrm{C}$ and $\Delta$, uncorrected for age, have been used extensively in occanography, and are an integral part of models and theories. For the present, therefore, we continue the editorial policy of using $\Delta$ notations for samples not corrected for age.

* Suggestions to Authors of the Reports of the United States Geological Survey, 6th ed, 1978, Supt of Documents, U S Govt Printing Office, Washington, DC 20402. 


\section{RADIOCARBON}

Editor: MINZF. STUIVER

Managing Editor: RFNFF S KRA

Published by

THE AMERICAN JOURNAI. OF SCIENCE

Editors: JOHN RODGiRs, JoHN H OSTROM, ROBERT A BFrntr

Managing Editor: MARIF C: CASEY

Published three times a year, in Winter, Spring, and Summer, at Yale University, New Haven, Connecticut 06511 .

Subscription rate $\$ 75.00$ (for institutions), $\$ 50.00$ (for individuals), available only in whole volumes. The price of the full volume 22 , nos. $1-4$, is $\$ 60.00$ for individuals and $\$ 80.00$ for institutions. The Procecdings of the Tenth International Radiocarbon Conference, vol 22 nos. 2 and 3 , are available for $\$ 60.00$. The Proceedings of the Fleventh International Radiocarbon Conference, Vol 25, No. 2, 1983, is $\$ 50.00$.

All correspondence and manuscripts should be addressed to the Managing Editor, RADIO(CARBON, Kline (ieology I aboratory, Yale University, 210 Whitney Ave, PO Box 6666, New Haven, Connecticut 06511.

Reprints. The minimum reprint order for each article will be 50 copies without cover. No reprints will be furnished free of charge unless page charges are paid. The cost of additional copies will, of course, be greater if the article is accompanied by plates involving unusual expense. Copies will be furnished with a printed cover giving the title, author, volume, page, and year, when specially ordered

Page charges. Fach institution sponsoring research reported in a technical paper or a date list, will be asked to pay a charge of $\$ 80.00$ per printed page. Institutions or authors paving such charges will be entitled to 100 free reprints without covers. No charges will be made if the author indicates that his institution is unable to pay them, and payment of page charges on an article will not in any case be a condition for its acceptance.

Back issues and price lists may be obtained from the office of RADIOCARBON.

Missing issues will be replaced without charge only if claim is made within three months (six months for India and Australia) after the publication date. Claim for missing issues will not be honored if absence results from failure by the subscriber to notify the Journal of an addres. change.

Illustrations should include explanation of symbols used. Copy that cannot be reproduced cannot be accepted; it should be capable of reduction to not more than 10 by 17.5 , all lettering being at least $1 / 6$ inch high after reduction. When necessary, one large map or table can be accepted, if it will not exceed 17.5 inches in width after reduction. Line drawings should be in black India ink on white drawing board, tracing cloth, or coordinate paper printed in blue and should be accompanied by clear ozalids or reduced photographs for use by the reviewers. Photographs should be positive prints. Photostatic and typewritten material cannot be accepted as copy for illustrations. Plates (photographs) and figures (line drawings) should each be numbered consecutively through each article, using arabic numerals. If two photographs form one plate, they are figures $\mathrm{A}$ and $\mathrm{B}$ of that plate. All measurements should be given in SI (metric units).

Cilations. A number of radiocarbon dates appear in publications without laboratory citation or refererence to published date lists. We ask that laboratories remind submitters and users of radiocarbon dates to include proper citation (laboratory number and date-list citation) in all publications in which radiocarbon dates appear.

Radiocarbon Measurements: Comprehensive Index, 1950-1965. This index covers all published ${ }^{14} \mathrm{C}$. measurements through Volume 7 of RADIOCARBON, and incorporates revisions made by all laboratories. It is available to all subscribers to RADIOCARBON at $\$ 20.00$ US per copy.

List of laboratories. The comprehensive list of laboratories at the end of each volume appears in the third number of each volume. Changes in names or addresses should be reported to the Managing Editor by May 1.

Annual Index. All dates appear in index form at the end of the third number of each volume. Authors of date lists are asked to supply indexed material of archaeologic samples only with their date lists. 


\section{CONTENTS}

25 Years of Tropospheric ${ }^{14} \mathrm{C}$ ( )bservations in Central Furope

Ingeborg Levin, Bernd Kromer, Hildegard Schoch-Fischer, Michael Bruns,

Marianne Münnich, Dietrich Berdau, John C Vogel,

and Karl Otto Münnich

I a Jolla Measurements of Radiocarbon in South German Oak Tree-Ring Chronologies

$T W$ Linick, HE Suess, and Bernd Becker

Contamination Studies on Mollusk Shell Samples

Tomasz Goslar and Mieczysław F Pazdur...

Woods Hole Oceanographic Institution Radiocarbon Laboratory:

Sample Treatment and Cas Preparation

Sheila Griffin and Ellen $R M$ Druffel

I)ATE I.ISTS

Mieczysław F Pazdur, Romuald Awsiuk, Andrzej Bluszcz, Tomasz Goslar Anna Pazdur, Adam Walanus, and Andrezej Zastawny

Gliwice Radiocarbon Dates X...

HAR A/ Walker and R L Otlet

Harwell Radiocarbon Measurements IV

PRL I) P Agrawal, RV Krishnamurthy, and Sheela Kusumgar

Physical Research Laboratory Radiocarbon Date List V

NOTES, COMMENTS, AND REMARKS

Amplitude of Sunspot-Dependent Radiocarbon Variations: Data from Corals and Wine

Mordeckai Magaritz, Israel Carmi, and Ziv Sirkes 